\author{
Magdalena Wójcik, dr \\ Uniwersytet Jagielloński \\ Instytut Informacji Naukowej i Bibliotekoznawstwa \\ magda.wojcik@uj.edu.pl;magda.a.wojcik@gmail.com
}

\title{
Strony internetowe bibliotek szkolnych jako narzędzie wspierające rozwijanie zainteresowań czytelniczych dzieci. Porównanie wyników badań z lat 2012 i 2014
}

School libraries' websites as a tool supporting development of children's reading interests. Comparison of research studies' results from the years 2012-2014

Magdalena Wójcik - asystent w Instytucie Informacji Naukowej i Bibliotekoznawstwa Uniwersytetu Jagiellońskiego. Jej zainteresowania badawcze obejmują problematykę nowych form komunikacji w Internecie, w tym szczególnie mediów społecznościowych i ich związków z działalnością instytucji książki.

Wybrane publikacje:

- Promocja literatury $w$ Internecie [Promotion of literature on the

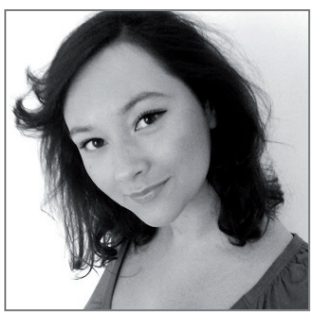
Internet], „Przegląd Biblioteczny”, 2010, z. 4

- Użytkownicy serwisów spotecznościowych poświęconych literaturze [Users of social networking sites devoted to literature], „Przegląd Biblioteczny”, 2012, z. 2

- Web 2.0 w dziatalności ustugowej instytucji książki [Web 2.0 in book institutions services], 2013.

Magdalena Wójcik - PhD, assistant at the Institute of Information and Library Science, Jagiellonian University. Her research interests include new forms of communication on the Internet, especially social media and their relation to the activities of the book institutions. 


\section{Wstęp}

Internet, media społecznościowe i technologie mobilne są dla młodego pokolenia czytelników naturalnym środowiskiem komunikacyjnym, służącym realizacji zróżnicowanych potrzeb - edukacyjnych, rozrywkowych czy społecznych (Izdebska J., Sosnowski T. (red.) 2005). Przyzwyczajenia związane z korzystaniem z nowych mediów wpływają jednocześnie na wiele aspektów życia dzieci i młodzieży, w tym także na ich oczekiwania względem bibliotek (Lewandowicz-Nosal G. 2009). Młodzi użytkownicy coraz częściej postrzegają działalność instytucji przez pryzmat jej obecności w sieci.

Dobrze zaprojektowana, interaktywna strona www może się więc stać wizytówką biblioteki (Sapa R. 2005), służącą promocji tak samej instytucji, jak i - w szerszym kontekście - kultury czytania. Biblioteki szkolne - w sposób szczególny powołane do propagowania czytelnictwa wśród dzieci i młodzieży - mogą wykorzystać szanse związane z rozwojem nowych narzędzi informacyjno-komunikacyjnych, by lepiej realizować swoje kluczowe zadania. Niestety, biblioteki te ze względu na swoją specyfikę - włączenie w strukturę szkoły i zależność od niej - muszą nierzadko borykać się nie tylko z problemami finansowymi i organizacyjnymi, ale przede wszystkim z brakiem niezależności decyzyjnej i niską pozycją w strukturze szkoły. Problemy te mogą znacznie spowalniać proces wdrażania do praktyki bibliotecznej wykorzystania nowych technologii. Odpowiedzi wymaga zatem pytanie: czy i w jakim stopniu biblioteki szkolne wykorzystują potencjał swoich stron www jako narzędzi mogących pobudzać zainteresowania czytelnicze uczniów? Wyniki analiz przedstawione w niniejszym artykule stanowią przyczynek do badań tej problematyki.

\section{Przedmiot i cel badań}

Przedmiotem badań jest zakres i sposób wykorzystania stron internetowych jako narzędzi wspierających rozwój zainteresowań czytelniczych dzieci. Głównym celem autorki jest sformułowanie wniosków dotyczących zmian w dynamice wykorzystania potencjału stron www bibliotek szkolnych jako narzędzi pobudzających rozwój zainteresowań czytelniczych dzieci, jakie zaszły między rokiem 2012 a 2014. Do celów szczegółowych należą:

- zidentyfikowanie elementów najczęściej występujących na stronach www bibliotek szkolnych,

- wytypowanie elementów stron www, których obecność może potencjalnie wspierać rozwijanie zainteresowań czytelniczych dzieci,

- określenie częstości występowania na stronach bibliotek szkolnych wytypowanych elementów, mogących korzystnie wpływać na proces aktywizacji czytelniczej dzieci, 
- wskazanie obszarów wykorzystania witryn bibliotecznych, które w latach 2012-2014 uległy największym zmianom,

- sformułowanie prognoz dotyczących potencjału dalszego wykorzystania bibliotecznych stron www jako elementów korzystnie wpływających na czytelnictwo dzieci.

\section{Stan badań}

Analiza stanu badań przeprowadzona w oparciu o analizę katalogu NUKAT i bazy BN pokazała, że problematyka aktywizacji czytelniczej dzieci i młodzieży była w latach 2000-2014 tematem stosunkowo często poruszanym. Problematyka czytelnictwa dzieci leżała nie tylko w polu zainteresowań bibliologii, ale także innych dziedzin, takich jak psychologia, socjologia czy pedagogika. Do problemów najczęściej poruszanych w polskiej literaturze przedmiotu należały następujące tematy:

- formy pracy z młodym czytelnikiem oraz metody aktywizacji czytelniczej dzieci i młodzieży (Baluch A. 2003; Papuzińska J., Walczewska-Klimczak G. (red.) 2004; Truskolaska J. 2007; Ungeheuer-Gołąb A. 2011),

- oferta wydawnicza dla dzieci i młodzieży (Zając M. 2002; Leszczyński G., Świerczyńska-Jelonek D., Zając M. (red.) 2006),

- funkcje książki dla dzieci (Chruścińska J., Kubisz E. (red.) 2000; Papuzińska J., Leszczyński G. (red.) 2002; Szczupał B. 2009; Łaba A. 2011),

- rola rodziny, szkoły, biblioteki w kształtowaniu zainteresowań czytelniczych (Chruścińska J., Kubisz E. (red.) 2002; Maciąg K. 2006; Lewandowicz-Nosal G. (red.) 2009),

- biblioterapia i bajkoterapia jako metody pracy z czytelnikiem dziecięcym (Molicka M. 2002; Szeliga K. 2008; Okrasa M. 2011; Bautsz-Sontag A. 2013).

Omawiając stan badań nad problematyką książki dla dzieci i młodzieży nie sposób pominąć istotnych prac zbiorowych, które ukazały się w ostatnim czasie, w tym szczególnie: Media a czytelnicy. Studia o komunikacji i uczestnictwie kulturowym mtodego pokolenia (Antczak M., Brzuska-Kępa A., Walczak-Niewiadomska A. (red.) 2013a) oraz Kultura czytelnicza dzieci i mtodzieży początku XXI wieku: szkice bibliologiczne (Tychże 2013b).

Zagadnienie wykorzystania środowiska Internetu w celu pobudzania aktywności czytelniczej dzieci i młodzieży - istotne z punktu widzenia przedmiotu badań - było najczęściej poruszane w kontekście problematyki rozwijania kompetencji informacyjnych - information literacy/media literacy (Kondracka M. 2009; Jaszczyszyn E. 2010). Analizom poddawano także wpływ popularności nowych mediów - w tym szczególnie dostępnych w sieci gier video i multimediów - na czytelnictwo dzieci i młodzieży (Izdebska J. 2007; Kozak s. 2011). Brakuje natomiast 
w polskiej literaturze przedmiotu prac prezentujących wyniki badań empirycznych dotyczących stopnia wykorzystania nowych narzędzi informacyjno-komunikacyjnych w pracy bibliotek szkolnych. Rzadko poruszano również problematykę wykorzystania elementów Web 2.0 jako narzędzi służących promowaniu czytelnictwa wśród młodych odbiorców.

\section{Organizacja i przebieg badań}

Badania przeprowadzone w latach 2012 i 2014 zostały zrealizowane według tej samej metodologii. Badanie podzielono na dwa etapy. W pierwszym - sprawdzono, które spośród 122 krakowskich szkół podstawowych posiadających własne strony www, udostępniają na swoich stronach internetowych informacje na temat istnienia biblioteki szkolnej, w drugim - strony bibliotek szkolnych zaklasyfikowano do jednej z dwóch kategorii: strony wizytówki - zawierające jedynie podstawowe informacje na temat biblioteki, rozmieszczone w obrębie jednej podstrony oraz rozbudowane - złożone z przynajmniej dwóch podstron. W odniesieniu do obu kategorii stron, analizie jakościowej poddano zakres i rodzaj występowania elementów wspierających rozwijanie zainteresowań czytelniczych dzieci, analizie ilościowej - częstość ich występowania na stronach badanych bibliotek. Pod uwagę brano - wytypowane w oparciu o analizę literatury przedmiotu - elementy mogące potencjalnie korzystnie wpływać na rozwój zainteresowań czytelniczych dzieci, takie jak:

- aktualności, informacje o bieżących działaniach biblioteki,

- wykazy nowych nabytków,

- recenzje i zestawienia polecanych książek,

- informacje o nowościach wydawniczych,

- informacje o akcjach promujących czytanie,

- wykazy linków do polecanych zasobów sieciowych,

- multimedia,

- gry dydaktyczne,

- aktywizujące elementy Web 2.0 itp.

Rezultaty badań z lat 2012 i 2014 poddano analizie porównawczej, co umożliwiło pokazanie dynamiki zmian w stopniu wykorzystywania stron www jako narzędzi aktywizujących czytelnictwo dzieci.

\section{Strony internetowe bibliotek szkolnych}

W świetle przeprowadzonych badań można stwierdzić, że w 2014 r. - w stosunku do roku 2012 - zwiększyła się z 30\% do 43\% liczba szkół informujących za pośrednictwem swoich stron www o działaniu bibliotek szkolnych (Wykres 1). 
Wykres 1. Biblioteki krakowskich szkół podstawowych posiadające strony www - porównanie wyników badań z lat 2012 i 2014

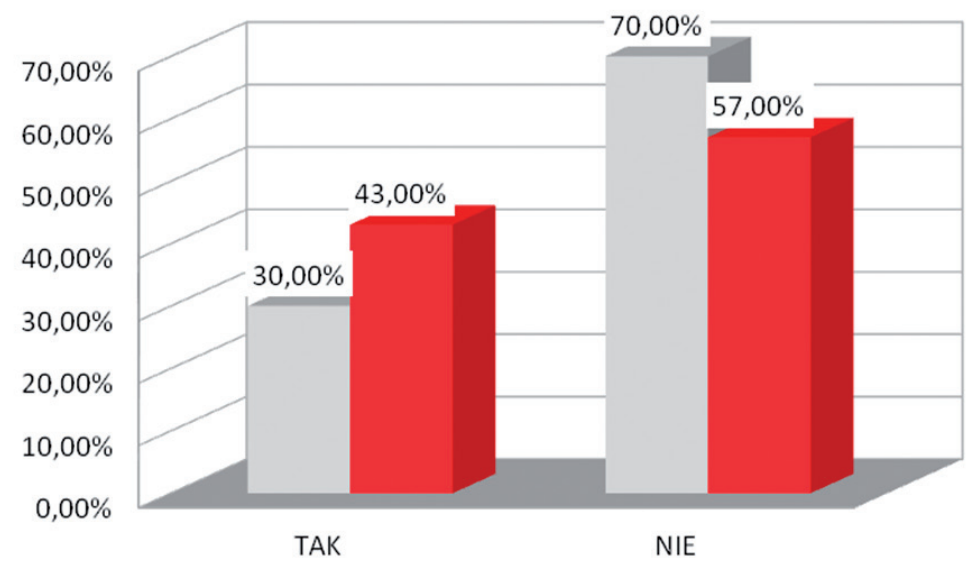

2012 r.

- 2014 r.

Źródło: oprac. własne, 12.05.2014.

Równocześnie zmniejszyła się widocznie, z 54\% do 30\%, liczba rozbudowanych portali bibliotecznych, na rzecz prostych stron wizytówek (Wykres 2).

\section{Wykres 2. Rodzaje stron internetowych bibliotek krakowskich szkół podstawowych}

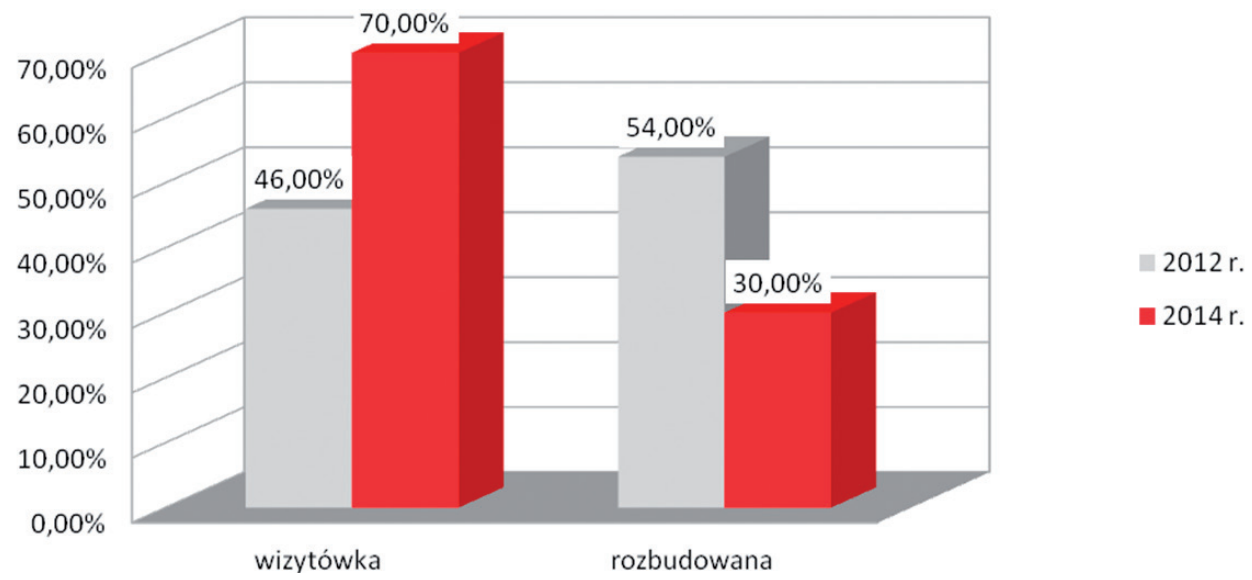

Źródło: oprac. własne, 12.05.2014.

W 2012 r. do najczęściej udostępnianych za pośrednictwem bibliotecznych stron www danych należały informacje o godzinach otwarcia biblioteki $(78 \%)$ oraz profilu gromadzonych zbiorów $(46 \%)$. Często publikowano także zdjęcia 
z organizowanych w bibliotece imprez (38\%), regulaminy korzystania ze zbiorów (35\%) oraz informacje o misji i działaniach biblioteki (30\%). Rzadziej informowano o udostępnianiu przez bibliotekę stanowisk komputerowych (19\%) oraz zamieszczano zestawienia obowiązujących uczniów podręczników i lektur (8\%) (Wykres 3).

W 2014 r. nadal najczęściej udostępniane były podstawowe informacje o godzinach otwarcia (72\%) i gromadzonych zbiorach (32\%) oraz regulaminy $(28 \%)$ i zdjęcia (23\%). Wyraźnie częściej udostępniano jednak informacje o obowiązujących uczniów lekturach i podręcznikach (15\%). Zdecydowanie rzadziej informowano natomiast o misji i zadaniach bibliotek (15\%) (Wykres 3).

Podsumowując, można zauważyć, że w 2014 r. odsetek bibliotek udostępniających poszczególne typy informacji zmniejszył się - w stosunku do roku 2012 - w obrębie wszystkich analizowanych kategorii, z wyjątkiem obszaru udostępniania informacji o lekturach i podręcznikach. Taka tendencja może wskazywać na postępujące zacieśnianie współpracy między biblioteką a nauczycielami poszczególnych przedmiotów.

Wykres 3. Standardowe elementy na stronach bibliotek krakowskich szkół podstawowych - porównanie wyników badań z lat 2012 i 2014

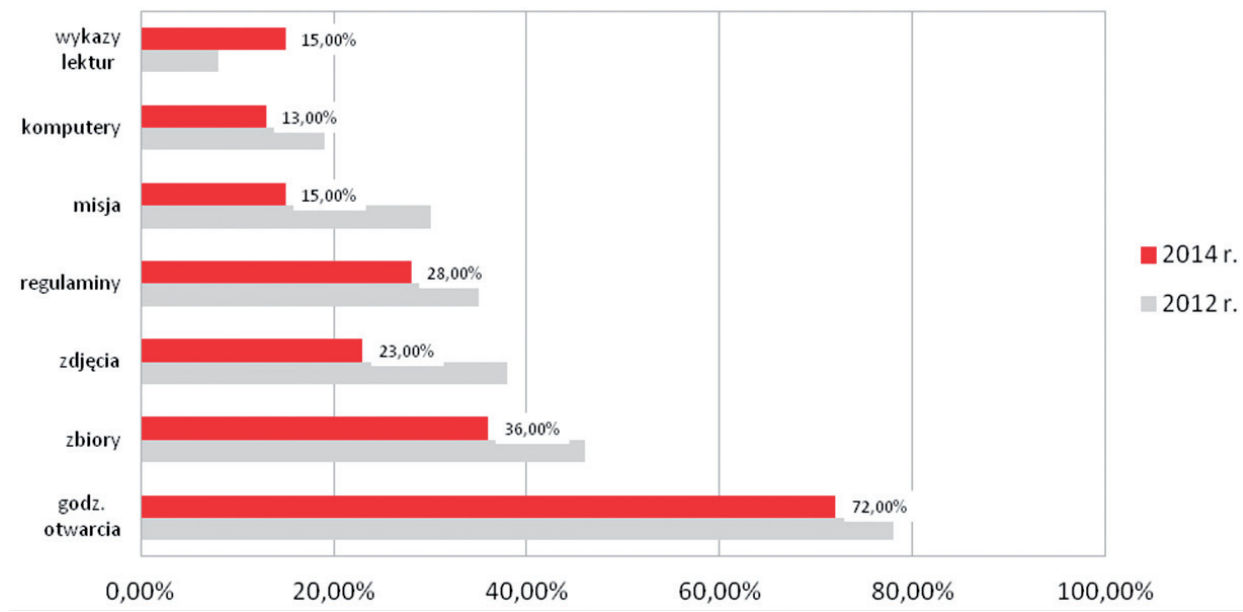

Źródło: oprac. własne, 12.05.2014.

\section{Strony internetowe jako narzędzie wspierające rozwijanie zaintere- sowań czytelniczych dzieci}

Spośród wytypowanych elementów mogących potencjalnie korzystnie wpływać na aktywizację czytelniczą dzieci, w 2012 r. najczęściej udostępniane były 
informacje o akcjach i konkursach związanych z czytaniem (30\%). Na kolejnych miejscach znalazły się aktualności z życia biblioteki (22\%), spisy polecanych książek (19\%) oraz szeroka kategoria „inne”, w skład której wchodziły zróżnicowane elementy, takie jak ciekawostki, rady dla rodziców czy przysłowia związane z książką (16\%). Stosunkowo często pojawiały się także informacje o nowych nabytkach $(13,5 \%)$, recenzje $(13,5 \%)$, linki do polecanych zasobów sieciowych $(13,5 \%)$ oraz statystyki dotyczące czytelnictwa uczniów (11\%). Rzadziej udostępniane były cytaty o książkach (8\%), multimedia (5\%), informacje o nowościach wydawniczych (3\%) i gry (3\%). W 2012 r. na stronie żadnej z analizowanych stron bibliotecznych nie znaleziono elementów Web 2.0 (0\%) (Wykres 4).

W 2014 r. zmieniły się nieco proporcje udostępnianych informacji. Najczęściej dzielono się informacjami o bieżących działaniach bibliotek (26\%), na drugim miejscu znalazły się informacje o konkursach i akcjach promujących czytanie (24\%), na trzecim i czwartym miejscu - podobnie jak w roku 2012 - znalazły się kolejno zestawienia polecanych książek (11\%) i kategoria „inne” (9\%). Dalej, statystyki czytelnictwa $(8 \%)$, cytaty $(8 \%)$, informacje o nowych nabytkach $(7,5 \%)$, recenzje $(6 \%)$ oraz - co warte odnotowania - elementy Web 2.0 (6\%). Rzadko udostępniano multimedia (4\%), informacje o nowościach wydawniczych $(2 \%)$ oraz gry (2\%) (Wykres 4).

Wykres 4. Elementy wspierające rozwijanie zainteresowań czytelniczych na stronach www bibliotek krakowskich szkół podstawowych - porównanie wyników badań z lat 2012 i 2014

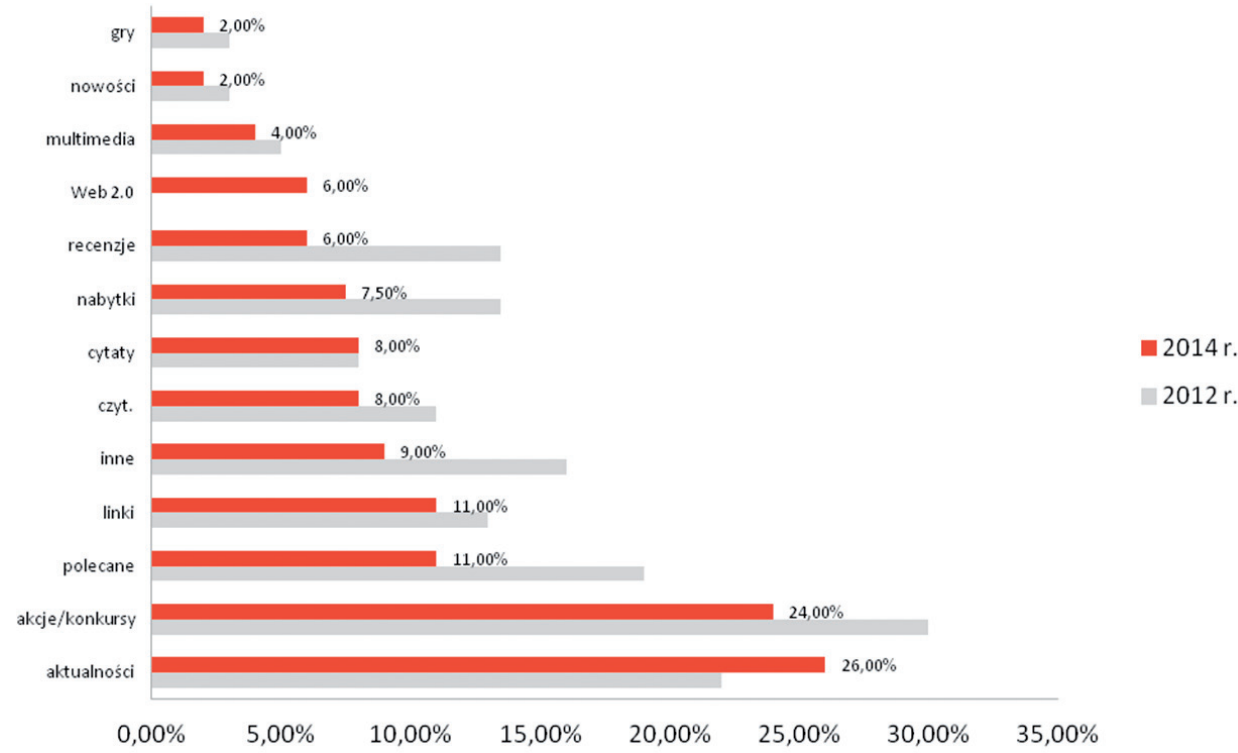

Źródło: oprac. własne, 12.05.2014. 
Zestawienie wskaźników procentowych z lat 2012 i 2014 pokazuje, że w przypadku elementów aktywizujących, podobnie jak w przypadku standardowych elementów stron, odsetek bibliotek udostępniających poszczególne kategorie informacji generalnie zmniejszył się w roku 2014. Wyjątkiem są dwie kategorie: aktualności, które udostępnia o 4\% więcej bibliotek i elementy Web 2.0, które w 2012 r. nie były w ogóle reprezentowane, a w 2014 były obecne na 6\% spośród analizowanych stron bibliotecznych (Wykres 4).

\section{Wnioski}

Przeprowadzone badania porównawcze pozwoliły na zrealizowanie zakładanych celów. W wyniku dokonanych analiz udało się zidentyfikować elementy najczęściej występujące na stronach www bibliotek szkolnych, wytypować elementy stron www, których obecność może potencjalnie wspierać rozwijanie zainteresowań czytelniczych dzieci oraz określić częstości ich występowania na stronach bibliotek szkolnych. Udało się również wskazać obszary wykorzystania witryn bibliotecznych, które w latach 2012-2014 uległy największym przeobrażeniom oraz sformułować prognozy dotyczące potencjału dalszego wykorzystania bibliotecznych stron www jako elementów aktywizujących czytelnictwo dzieci i młodzieży.

Przeprowadzone badania pozwolity stwierdzić, że strony bibliotek szkolnych nie są postrzegane jako istotny element promocji szkoły. Chociaż zwiększył się odsetek szkół informujących za pośrednictwem swoich stron www o istnieniu biblioteki szkolnej (z 30\% do 43\%), to jednak duża część spośród analizowanych stron bibliotek (70\%) ma charakter prostych wizytówek, dających jedynie niewielki wgląd w sposób działania biblioteki i jej istotną rolę w procesie edukacji szkolnej.

$\mathrm{Na}$ uwagę zasługuje fakt, że duży odsetek szkół, które nie informują o działaniu biblioteki lub czynią to w sposób bardzo oszczędny, informuje jednocześnie o szczegółach działania świetlicy szkolnej, gabinetu pedagoga, chóru szkolnego, gazetki czy działających w szkole kół zainteresowań. Zdarza się również, choć na szczęście rzadko, że informacje o działaniu biblioteki są zamieszczane na stronie szkoły nie w zakładce „oferta edukacyjna”, ale w sekcji „administracja”, razem z informacją o szatni i stołówce, a więc podmiotami, które choć istotne, pełnią jednak zdecydowanie inne funkcje niż biblioteka.

Zestawienie wyników badań z lat 2012 i 2014 pokazuje, że zarówno w przypadku standardowych elementów bibliotecznych stron www, jak i elementów aktywizujących, odsetek bibliotek udostępniających poszczególne kategorie informacji generalnie zmniejszył się w roku 2014. Wyjątek stanowią jedynie dwie kategorie: aktualności, które udostępnia o 4\% więcej bibliotek niż w roku 2012 oraz elementy Web 2.0, które w 2012 r. nie były w ogóle obecne na stronach krakowskich bibliotek szkół podstawowych, a w 2014 można je było znaleźć na 
6\% spośród analizowanych stron. Warstwa wizualna większości witryn bibliotek szkolnych jest nadal bardzo uboga, tak pod względem projektów graficznych, jak i funkcjonalnych, co może zniechęcać uczniów do korzystania z nich i przyczyniać się do formowania niekorzystnego wizerunku biblioteki. Pozytywnym elementem zaobserwowanym w 2014 r. jest pojawienie się na stronach bibliotek szkolnych elementów o charakterze społecznościowym, najczęściej w formie linków do profili bibliotek w serwisach społecznościowych typu Facebook czy Twitter. Może to sugerować, że biblioteki szkolne pomimo trudnej sytuacji, próbują uatrakcyjniać swoje strony www o elementy lubiane przez dzieci i młodzież.

Podsumowując wyniki przeprowadzonych badań można stwierdzić, że potencjał stron internetowych bibliotek szkolnych, jako narzędzi mogących korzystnie stymulować procesy aktywizacji czytelniczej, nie jest jeszcze w pełni wykorzystywany. Konieczne wydaje się przede wszystkim stałe propagowanie informacji o misji i zadaniach bibliotek szkolnych wśród kierownictwa szkół, dążenie do poprawy jakości wizualnej i technicznej witryn bibliotecznych oraz stałe uzupełnianie ich struktury o atrakcyjne elementy multimedialne i społecznościowe.

\section{Bibliografia}

Antczak M., Brzuska-Kępa A., Walczak-Niewiadomska A. (red.) (2013a), Media a czytelnicy. Studia o komunikacji i uczestnictwie kulturowym mtodego pokolenia, Łódź, Wydaw. Uniwersytetu Łódzkiego, ISBN 978-83-7525-990-2

Antczak M., Brzuska-Kępa A., Walczak-Niewiadomska A. (red.) (2013b), Kultura czytelnicza dzieci i mtodzieży początku XXI wieku: szkice bibliologiczne, Łódź, Wydaw. Uniwersytetu Łódzkiego, ISBN 978-83-7969-027-5

Baluch A. (2003), Od ludus do agora: rozważania o ksiażkach dla dzieci i mtodzieży i o sposobach lektury, które wioda od zabawy do poważnej rozmowy o literaturze, Kraków, Wydaw. Naukowe Akademii Pedagogicznej, ISBN 83-7271-225-5

Bautsz-Sontag A. (2013), Literatura $w$ terapii dzieci, Katowice, Oficyna Wydawnicza Wacław Walasek, ISBN 978-83-60743-81-2

Chruścińska J., Kubisz E. (red.) (2002), Dziecko, rodzina, biblioteka: materiaty z konferencji ogólnopolskiej, Zielona Góra, 18-19 września 2001 r., Warszawa, CEBID, ISBN 83-88581-04-X

Chruścińska J., Kubisz E. (red.) (2000), Walory edukacyjne literatury dziecięcej: ogólnopolskie seminarium organizatorów czytelnictwa dziecięcego, Białystok, 11-13 maja 1999, Warszawa, CUKB, ISBN 83-909574-7-7

Izdebska J. (2007), Dziecko w świecie mediów elektronicznych: teoria, badania, edukacja medialna, Białystok, Wydaw. Uniwersyteckie Trans Humana, ISBN 97883-89190-94-9 
Izdebska J., Sosnowski T. (red.) (2005), Dziecko i media elektroniczne: nowy wymiar dziecinstwa. T. 2, Komputer i Internet w życiu dziecka i obraz jego dzieciństwa, Białystok, Trans Humana, ISBN 83-89190-59-1

Jaszczyszyn E. (2010), Modele edukacji czytelniczej w przedszkolu a gotowość do czytania i umiejętności czytania dzieci sześcioletnich, Białystok, Trans Humana Wydaw. Uniwersyteckie, ISBN 978-83-61209-43-0

Kondracka M. (2009), Wykorzystanie technologii informacyjnych $w$ nauce czytania i pisania dzieci w mtodszym wieku szkolnym przez nauczycieli wybranych szkót podstawowych - raport z badań [w:] Kobylarek A. (red. nauk.), Wspólnota i różnica: interdyscyplinarne studia, analizy i rozprawy, Toruń, Wydaw. Adam Marszałek, s. 262-272

Kozak S. (2011), Patologie komunikowania w Internecie: zagrożenia i skutki dla dzieci i mtodzieży, Warszawa, Difin, ISBN 978-83-7641-388-4

Leszczyński G., Świerczyńska-Jelonek D., Zając M. (red.) (2006), Książka dziecięca 1990-2005: konteksty kultury popularnej i literatury wysokiej: praca zbiorowa, Warszawa, Wydaw. SBP, ISBN 83-89316-62-5

Lewandowicz-Nosal G. (red.) (2009), Internet w bibliotece dla dzieci i mtodzieży, Warszawa, Wydaw. SBP, ISBN 978-83-61464-14-3

Łaba A. (2011), Zastosowanie biblioterapii w ksztattowaniu zachowań przystosowawczych uczniów z upośledzeniem umystowym $w$ stopniu lekkim, Lublin, Wydaw. Uniwersytetu Marii Curie-Skłodowskiej, ISBN 978-83-7784-047-4

Maciąg K. (2006), Miejsce bibliotek publicznych w systemie edukacji, Warszawa, Biblioteka Narodowa, ISBN 83-7009-454-6

Molicka M. (2002), Bajkoterapia: o lękach dzieci i nowej metodzie terapii, Poznań, Media Rodzina, ISBN 83-7278-041-2

Okrasa M. (2011), Biblioterapia w pracy z dziećmi i mtodzieża [w:] Wosik-Kawala D., Zubrzycka-Maciąg T. (red. nauk.), Kompetencje diagnostyczne i terapeutyczne nauczyciela, Kraków, Oficyna Wydawnicza Impuls, s. 207-226

Papuzińska J., Leszczyński G. (red.) (2002), Kultura literacka dzieci i mtodzieży u progu XXI stulecia: praca zbiorowa, Warszawa, CEBID, ISBN 83-88581-06-6

Papuzińska J., Walczewska-Klimczak G. (red.) (2004), Animacja czytelnictwa dziecięcego: koncepcje, doświadczenia, postulaty: praca zbiorowa, Płock, Książnica Płocka im. W. Broniewskiego, Płockie Stowarzyszenie Przyjaciół Książki i Bibliotek, ISBN 83-88028-27-8

Sapa R. (2005), Benchmarking $w$ doskonaleniu serwisów WWW bibliotek akademickich, Kraków, Wydaw. UJ, ISBN 83-233-1963-4

Szczupał B. (2009), O literaturze dla dzieci i mtodzieży z niepetnosprawnością: recepcja, edukacja, terapia, wsparcie, twórczość, Warszawa, Dom Wydawniczy Elipsa, ISBN 978-83-7151-862-1

Szeliga K. (2008), Bajkoterapia czyli Jak z Guziolkiem tworzyć i wykorzystywać bajki $i$ opowiadania $w$ biblioterapii oraz rozwoju aktywności twórczej dziecka 
w wieku przedszkolnym: ogólnopolski Konkurs Literacki pt. Razem z Guziolkiem piszemy bajki 2007/2008, Kraków, Impuls, ISBN 978-83-7587-114-2

Truskolaska J. (2007), Wychować mitośnika książki czyli Czytelnictwo i okolice, Tychy, Maternus Media, ISBN 978-83-89701-35-0

Ungeheuer-Gołąb A. (2011), Rozwój kontaktów matego dziecka z literatura: podręcznik, Warszawa, Rzeszów, Wydaw. SBP, Uniwersytet Rzeszowski, ISBN 978 83-61464-92-1

Zając M. (2002), Raport o ksiażce dla dzieci i mtodzieży, Warszawa, Biblioteka Analiz, ISBN 83-89143-03-8

\begin{abstract}
Abstrakt
Przedmiotem artykułu są sposoby wykorzystania stron www jako narzędzi stymulujących rozwój zainteresowań czytelniczych dzieci. Głównym celem było porównanie wyników badań przeprowadzonych w 2012 r. z analogicznymi badaniami przeprowadzonymi w 2014 r. Analizie jakościowej poddano zakres i rodzaj występowania na stronach www bibliotek krakowskich szkół podstawowych elementów wspierających proces aktywizacji czytelniczej dzieci. W badaniu pod uwagę wzięto: informacje o bieżącej ofercie biblioteki, wykazy nowych nabytków, informacje o nowościach wydawniczych, recenzje, zestawienia polecanych książek, informacje o akcjach promujących czytanie, wykazy linków do polecanych zasobów sieciowych, multimedia, gry dydaktyczne, aktywizujące elementy Web 2.0 itp. Analizie ilościowej poddano częstość występowania tych elementów na stronach bibliotek. Wykorzystane metody badawcze to: sondaż diagnostyczny i analiza porównawcza. W rezultacie przeprowadzonych badań sformułowano wnioski dotyczące dynamiki zmian w zakresie i sposobach wykorzystywania potencjału stron internetowych jako narzędzi wspierających rozwój zainteresowań czytelniczych.
\end{abstract}

\begin{abstract}
The paper discusses a problem of Internet websites' role in stimulating development of children's reading interests. The main objective of the study was to compare the results of the research carried out in 2012, with similar projects conducted in 2014. Cracow primary school libraries' websites were analyzed qualitatively to discover the extent and type of elements supporting the process of activating reading among children. The analysis included: information about the current library offerings, listings of new acquisitions, publishing news, reviews, the lists of recommended books, information about reading promotion actions, lists of recommended links to web resources, multimedia, educational games, activating elements of Web 2.0, etc. Frequency of occurrence of these elements on the surveyed websites was analyzed quantitatively. As a result, conclusions regarding dynamics of changes in the scope and ways of using libraries websites as potential tools for supporting development of children's interests in reading were formulated.
\end{abstract}

